\title{
Interim Action Proposed Plan for the Old Radioactive Waste Burial Ground (643-E)
}

by

S. McFalls

Westinghouse Savannah River Company

Savannah River Site

Aiken, South Carolina 29808

DOE Contract No. DE-AC09-89SA18035

This paper was prepared in connection with work done under the above contract number with the U.S. Department of Energy. By acceptance of this paper, the publisher and/or recipient acknowledges the U.S. Government's right to retain a nonexclusive, royalty-free license in and to any copyright covering this paper, along with the right to reproduce and to authorize others to reproduce all or part of the copyrighted paper.

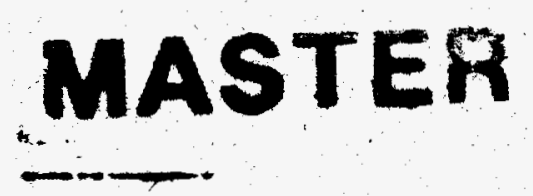




\section{DISCLAMIER}

Portions of this document may be illegible in electronic image products. Images are produced from the best available original document. 


\section{United States Department of Energy}

Savannah River Site

\section{Interim Action Proposed Plan for the Old Radioactive Waste Burial Ground (643-E) (U)}

WSRC-RP-94-1225

Revision 1

December 1995

Westinghouse Savannah River Company Savannah River Site Aiken, South Carolina 29808

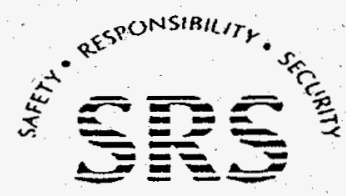




\section{DISCLAMMER}

This report was prepared as an account of work sponsored by an agency of the United States Government. Neither the United States Government nor any agency thereof, nor any of their employees, makes any warranty, express or implied, or assumes any legal liability or responsibility for the accuracy, completeness, or usefulness of any information, apparatus, product, or process disclosed, or represents that its use would not infringe privately owned rights. Reference herein to any specific commercial product, process, or service by trade name, trademark, manufacturer, or otherwise does not necessarily constitute or imply its endorsement, recommendation, or favoring by the United States Government or any agency thereof. The views and opinions of authors expressed herein do not necessarily state or reflect those of the United States Government or any agency thereof.

This report has been reproduced directly from the best available copy.

Available to DOE and DOE contractors from the Office of Scientific and Technical Information, P.O. Box 62, Oak Ridge, TN 37831; prices available from (615) 576-8401.

Available to the public from the National Technical. Information Service, U.S. Department of Commerce, 5285 Port Royal Road, Springfield, VA 22161. 


\section{Table of Contents}

Table of Contents

List of Tables.

List of Figures.

List of Acronyms

i.

Section I

Introduction and Background 1

Section II

Community Involvement 5

Section III Scope and Role of Operable Unit or Response Action Within the Site Strategy

Section IV

Media Specific Operable Unit - The ORWBG Unit.

Section IV.A Unit Description, History, and Media to be Addressed .8

Section IV.B Operable Unit Risks 10

Section IV.C Summary of Considered Alternatives

Section IV.D Evaluation of the Altematives and the Preferred Alternative.

References

Glossary 


\section{List of Tables}

Table 1: Applicable or Relevant and Appropriate Requirements (ARARs) and To-Be-Considered (TBC) Guidance.

Table 2: Evaluation of Alternative Actions Considered for Remediation of ORWBG

Contamination 18

\section{List of Figures}

Figure 1: Location of the Burial Ground Complex at the Savannah River Site..................3

Figure 2: Location of the Old Radioactive Waste Disposal Facility...............................4

Figure 3: Burial Ground Complex Project Schedule ................................................ 7

Figure 4: General Locations of Disposal Sections in the Old Radioactive Waste Disposal Facility.

Figure 5: Old Radioactive Waste Disposal Facility Soil Cover Configuration 20 


\section{List of Acronyms}

\begin{tabular}{|c|c|}
\hline ALARA & As Low As Reasonably Achievable \\
\hline ARARs & Applicable or Relevant and Appropriate Requirements \\
\hline BGC & Burial Ground Complex \\
\hline CERCLA & Comprehensive Environmental Response, Compensation and Liability Act \\
\hline CFR & Code of Federal Regulations \\
\hline $\mathrm{Ci}$ & Curies \\
\hline COCs & Constituents of Concern \\
\hline DOE & United States Department of Energy \\
\hline EPA & United States Environmental Protection Agency \\
\hline FFA & Federal Facility Agreement \\
\hline FIP & Field Investigation Plan \\
\hline FY & Fiscal Year \\
\hline IAPP & Interim Action Proposed Plan \\
\hline IROD & Interim Record of Decision \\
\hline LLRWDF & Low Level Radioactive Waste Disposal Facility \\
\hline $\mathbf{m L}$ & milliliters \\
\hline MWMF & Mixed Waste Management Facility \\
\hline NCP & National Oil and Substances Pollution Contingency Plan \\
\hline NPDES & National Pollutant Discharge Elimination System \\
\hline NPL & National Priorities List \\
\hline ORWBG & Old Radioactive Waste Burial Ground \\
\hline OU & Operable Unit \\
\hline PCE & Tetrachloroethylene \\
\hline $\mathrm{pCi}$ & picoCuries \\
\hline PIP & Public Involvement Plan \\
\hline ppbv & Parts Per Billion Volume \\
\hline RCRA & Resource Conservation and Recovery Act \\
\hline RFI & RCRA Facility Investigation \\
\hline SCDHEC & South Carolina Department of Health and Environmental Control \\
\hline SRS & Savannah River Site \\
\hline TBC & To-Be-Considered \\
\hline TBP & Tributylphosphate \\
\hline
\end{tabular}


Interim Action Proposed Plan for the

Old Radioactive Waste Burial Ground (643-E)

Savannah River Site
WSRC-RP-94-1225

Revision 1

December 1995

\section{List of Acronyms (continued)}

TCE

Trichloroethylene

TRU

Transuranic

WSRC

Westinghouse Savannah River Company 


\section{SECTION I}

\section{INTRODUCTION AND BACKGROUND}

\section{Introduction}

This Interim Action Proposed Plan (IAPP) is issued by the U.S. Department of Energy (DOE), which functions as the lead agency for SRS remedial activities, and with concurrence by the U.S. Environmental Protection Agency (EPA) and the South Carolina Department of Health and Environmental Control (SCDHEC). The purpose of this IAPP is to describe the preferred interim remedial action for addressing the Old Radioactive Waste Burial Ground (ORWBG) unit located in the Burial Ground Complex (BGC) at the Savannah River Site (SRS) in Aiken, South Carolina.

On December 21, 1989, SRS was included on the National Priorities List (NPL). In accordance - with Section 120 of the Comprehensive Environmental Response, Compensation, and Liability Act (CERCLA), DOE has negotiated a Federal Facility Agreement (FFA, 1993) with EPA and SCDHEC to coordinate remedial activities at SRS.

Public participation requirements are listed in Sections 113 and 117 of CERCLA. These requirements include establishment of an Administrative Record File that documents the selection of remedial alternatives and allows for review and comment by the public regarding those alternatives. The SRS Public Involvement Plan (PIP) (DOE, 1994) is designed to facilitate public involvement in the decision-making process for permitting, closure, and the selection of remedial alternatives. Section 117(a) of CERCLA, 1980 , as amended, requires publication of a notice of any proposed remedial action.

This IAPP is a summary of the Administrative Record File leading to the preferred interim remedial alternative. This
IAPP fulfills the requirements of CERCLA Section 117(a) by providing the public an opportunity to participate in the selection of a remedial action. This IAPP also satisfies the requirements of $a$ Resource Conservation and Recovery Act (RCRA) Interim Measure Work Plan.

The IAPP presents the proposed interim action and the rationale for selecting the alternative. DOE, in consultation with EPA and SCDHEC, will make the selection of the interim action at the ORWBG. The final decision will be made only after the public comment period has ended and all comments submitted have been reviewed and considered.

In order to gain a better understanding of CERCLA activities as they pertain to the ORWBG, the public is encouraged to review the Administrative Record File for this unit. Refer to Section II of this document for information regarding availability and access.

\section{Background}

SRS occupies approximately 310 square miles of land adjacent to the Savannah River, principally in Aiken and Barnwell counties of South Carolina (Figure 1). SRS is a secured U.S. Government facility with no permanent residents. SRS is located approximately 25 miles southeast of Augusta, Georgia and 20 miles south of Aiken, South Carolina.

SRS is owned by the U.S. DOE Management and operating services are provided by Westinghouse Savannah River Company (WSRC). SRS has historically produced tritium, plutonium, and other special nuclear materials for national defense. Chemical and radioactive wastes are by-products of nuclear material production processes. Hazardous substances, as defined by CERCLA, are currently present in the environment at SRS. 
SRS manages materials that are regulated under RCRA Certain SRS activities have required operating or post-closure permits under RCRA. SRS received a RCRA hazardous waste permit from SCDHEC on September 30, 1987. Part V of the permit mandates that SRS establish and implement an RFI Program to fulfill the requirements specified in RCRA Section 3004(u).

The BGC is an area which occupies approximately 195 acres in the central part of SRS between F-and H-Separations Areas, on a nearly flat divide between Upper Three Runs Creek to the north and Four Mile Creek to the south.

The BGC includes the ORWBG (Figure 2) and other operable units such as the Mixed Waste Management Facility (MWMF) (closed under RCRA), Solvent Tanks S1 S22, Solvent Tanks S23 - S30, Solvent Tank S32 (closed under RCRA), and the Low Level Radioactive Waste Disposal Facility (LLRWDF).

The ORWBG comprises a disposal area for solid radioactive waste produced at the SRS, as well as shipments from other U.S. Department of Energy and Department of Defense facilities. The ORWBG, designated Building Number 643-E, has a quadrilateral shape and occupies approximately 76 acres. The ORWBG has contributed to localized shallow aquifer groundwater contamination. Other RCRA/CERCLA units within the BGC are undergoing characterization and investigation to determine impacts to the environment.

Community involyement in consideration of this evaluation of alternatives for the ORWBG is strongly encouraged. All submitted comments will be reviewed and considered. A Responsiveness Summary to address issues raised by the public will be made available following the public comment period, if any comments have been received. Specific details on community participation in the corrective action selection process are provided in Section II. 


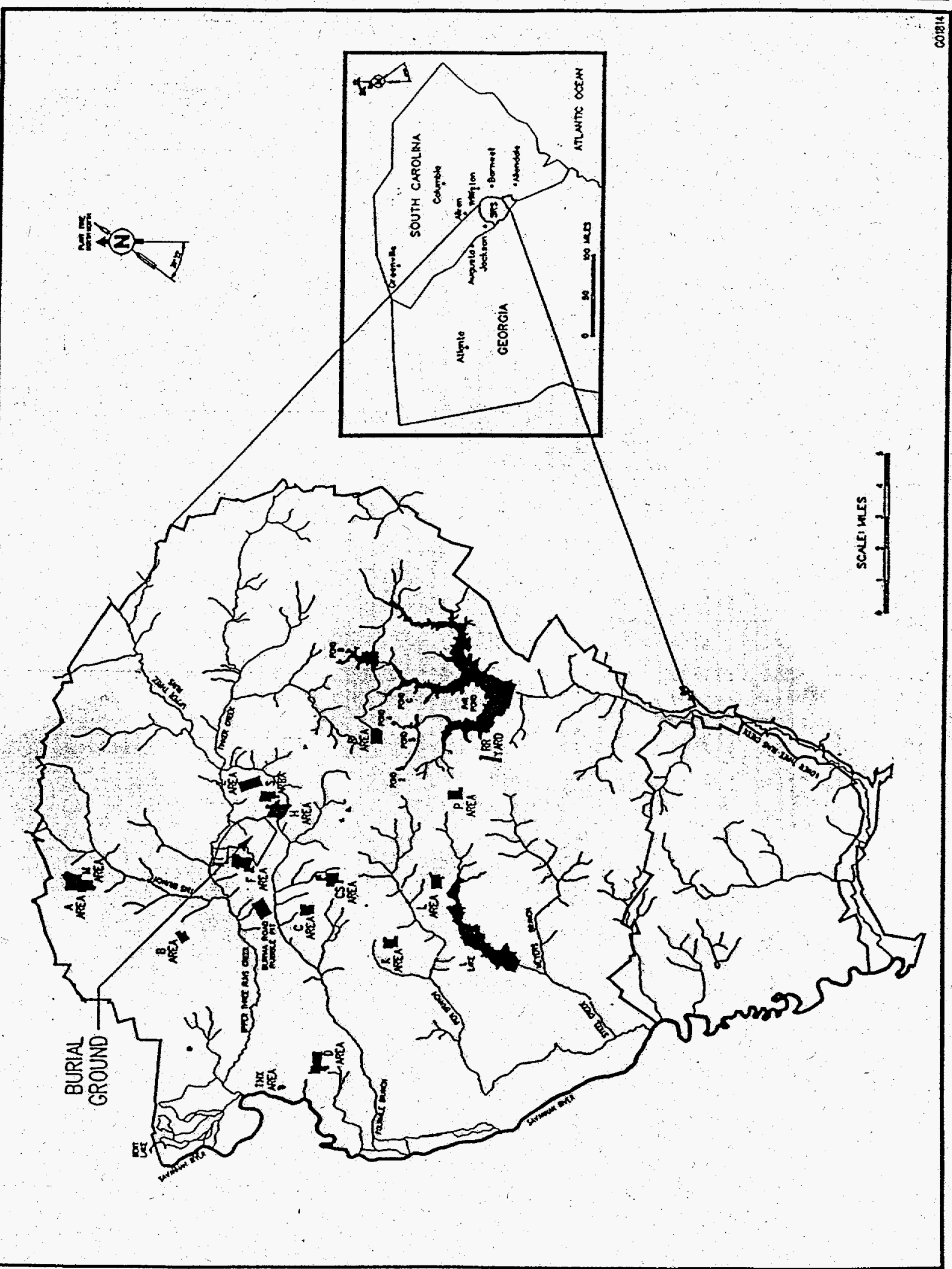

Figure 1. Location of the Burial Ground Complex at the Savannah River Site. 
Interim Action Proposed Plan for the

Old Radioactive Waste Burial Ground (643-E)

Sávannah River Site
WSRC-RP-94-1225

Revision 1

December 1995

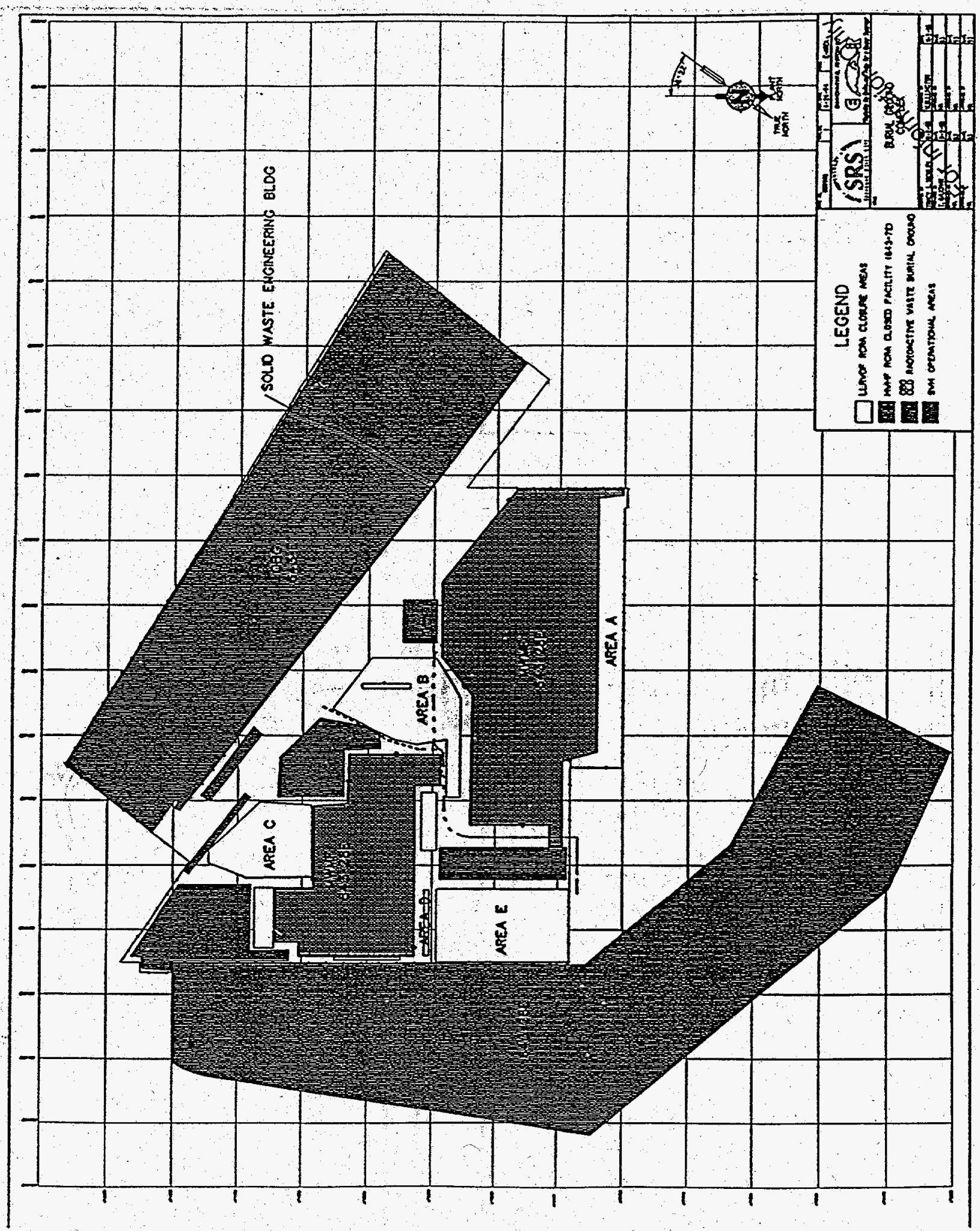

Figure 2. Location of the Old Radioactive Waste Disposal Facility. 


\section{SECTION II}

\section{COMMUNTTY INVOLVEMENT}

This document summarizes information that is provided in greater detail in the Administrative Record File, which is available for review by the public at the following locations:

\section{U. S. Department of Energy}

Public Reading Room

Gregg-Graniteville Library

University of South Carolina-Aiken

171 University Parkway

Aiken, South Carolina 29801

(803) $641-3465$

Thomas Cooper Library

Government Documents Department

University of South Carolina

Columbia, South Carolina 29208

(803) $777-4866$

Similar information is available through the repositories listed below:

Reese Library

Augusta College

2500 Walton Way

Augusta, Georgia 30910

(706) $737-1744$

Asa H. Gordon Library

Savannah State College

Tompkins Road

Savannah, Georgia 31404

(912) $356-2183$

The public will be notified of a public comment period through mailing of the $S R S$ Environmental Bulletin, a newsletter sent to approximately 1400 citizens in South Carolina and Georgia, and through notices in the Aiken Standard, the Allendale Citizen Leader, the Barnwell County Banner, the Barnwell People-Sentinel, the North Augusta Post, The State, and the Augusta Chronicle newspapers.
DOE will provide opportunity for a public meeting during the public comment period if interest is expressed. The public would be notified of the date, time, and location. At the meeting, the proposed action would be discussed and questions about the action will be answered. Written and oral comments will be accepted and considered prior to a final decision. To request a public meeting during the public comment period, to obtain more information concerning this IAPP, or to submit writter comments contact:

Mary A. Flora

Public Involvement

Westinghouse Savannah River Company

Savannah River Site

Building 730-2B, Room 128

Aiken, South Carolina 29808

(803) $952-6852$

DOE, EPA and SCDHEC strongly encourage community participation in the review of the IAPP for the ORWBG waste unit A Responsiveness Summary to address issues raised by the public will be made available following the public comment period, if any comments have been received. DOE, EPA, and SCDHEC solicit public review and comment on all aspects of the IAPP.

DOE, in consultation with EPA and SCDHEC, will select the final remedial action to be performed at the ORWBG waste unit following the public comment period. The alternative chosen must be protective of human health and the environment and comply with all Federal and state environmental laws. 


\section{SECTION III}

\section{SCOPE AND ROLE OF OPERABLE UNIT OR RESPONSE ACTION WTHHIN THE SITE STRATEGY}

The BGC includes the ORWBG and other operable units (OUs) such as the MWMF (closed under RCRA), Solvent Tanks S1 S22, Solvent Tanks S23 - S30, Solvent Tank S32 (closed under RCRA), and the LLRWDF. "The overall plan for characterization and remediation at the BGC is presented in Figure 3. This figure shows both RCRA and CERCLA estimated project schedules for the major activities at the BGC.

The entire BGC is listed as one OU under CERCLA. The investigation/ assessment process will address all of the facilities, including those which have been closed under RCRA. Once appropriate characterization data is available and a risk analysis has been performed, a final remedial action for the BGC will be implemented. The MWMF was closed (via capping) under RCRA and had a ROD issued in fiscal year (FY) 1993. The LLRWDF is slated to be closed (via capping) under RCRA beginning in FY 1996.

Characterization for the BGC is currently ongoing through the BGC Field Investigation Plan (FIP) and will encompass environmental releases from all facilities within the BGC (MWMF, LLRWDF, ORWBG, etc.). Characterization data currently available for the BGC indicates that the ORWBG has contributed to localized shallow aquifer contamination. Given this information and the current FFA process schedule for the BGC (remedial action currently planned to begin in FY 2001 ), an interim action is proposed for the ORWBG.

The role of the proposed interim action at the ORWBG unit is a reduction in stormwater infiltration through the waste layer which should minimize contaminant migration to the water table. The interim action proposes to place a low-permeability soil cover over the ORWBG unit. Topsoil with a vegetative cover will also be a part of the interim action. The soil cover will be sloped to promote surface runoff, minimize surface erosion, and control the leaching of hazardous substances from the source material.

This interim action addresses source control at the ORWBG in advance of the final remedial action for the BGC. The proposed soil cover is consistent with the overall site strategy because it provides for a reduction in contaminant migration without hindering ongoing characterization efforts conducted as part of the BGC FIP and without precluding any final remedial action developed during the FFA process for the BGC. 


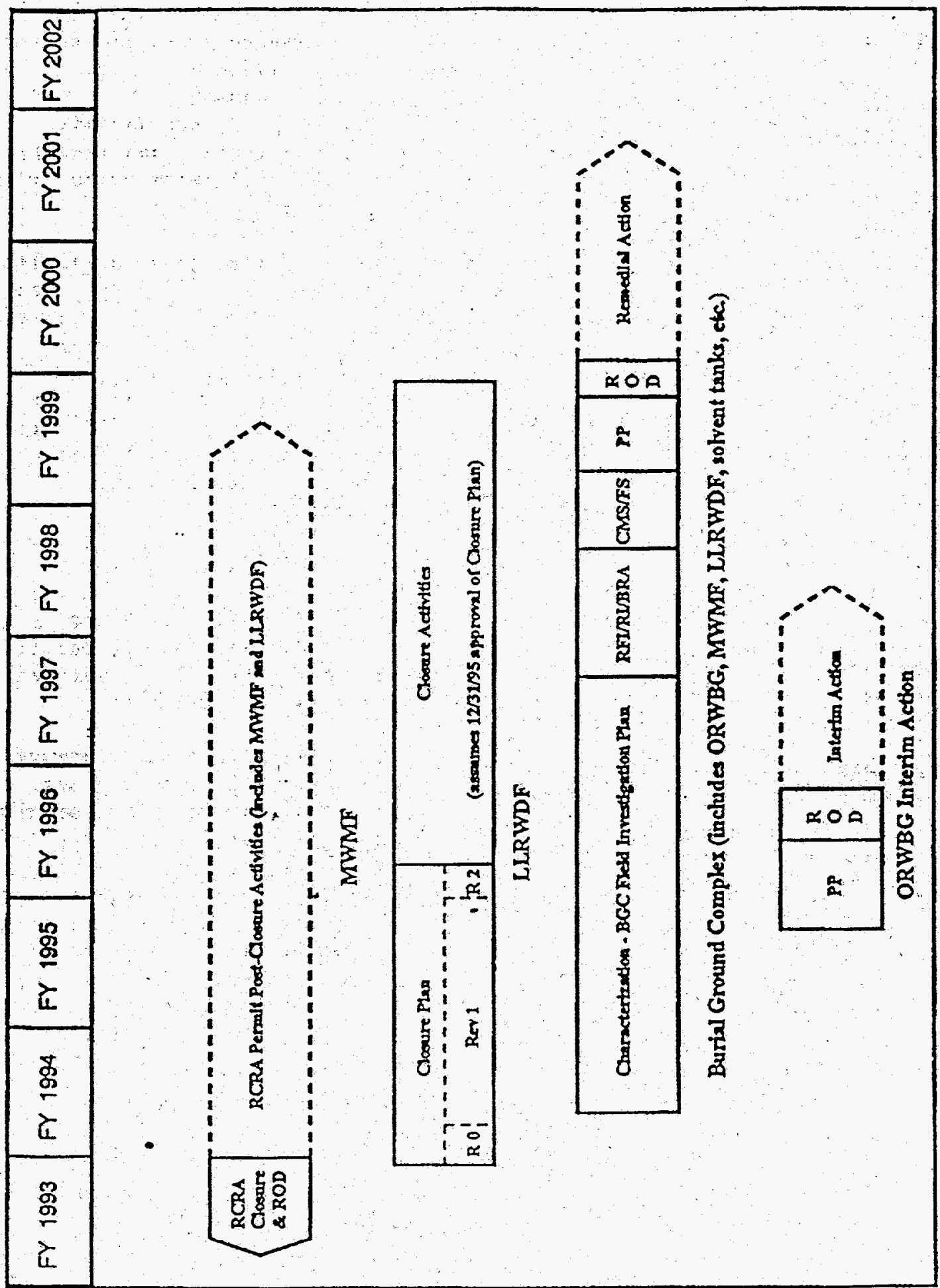

Note: The dotted lines represent approximate activity durations.

Figure 3. Burial Ground Complex Project Schedule. 


\section{SECTION IV}

\section{MEDIA SPECIFIC OPERABLE UNIT - THE ORWBG UNIT}

Section IV.A Unit Description, History,
and Media to be Addressed

\section{Unit Description and Location}

The ORWBG, 643-E, comprises a disposal area for solid radioactive waste produced at the SRS, as well as shipments from other U.S. Department of Energy and Department of Defense facilities. The ORWBG has a quadrilateral shape and occupies approximately 76 acres in the southem part of the BGC (Figure 2). The nearest SRS boundary is over six miles to the north.

\section{History of the Unit}

The history of the ORWBG is summarized from the Phase II RFI/RI Work Plan for the Burial Ground Complex (WSRC, 1994).

The ORWBG began receiving waste in 1952 and was filled in 1972. The ORWBG was divided into sections to accommodate disposal of various levels/types of radioactive waste materials (Figure 4). These materials include transuranic (TRU) waste, low-level waste, and intermediatelevel waste generated at SRS; and waste generated elsewhere.

Examples of materials disposed of at the ORWBG include the following:

- Incidental waste from laboratory and production operations,

- Contaminated equipment,

- Lead,

- Reactor hardware,

- Spent deionizer resins,

- . Spent lithium-aluminum targets,

- Irradiated process oil from pumps in the tritium facilities and reactor areas,
- Mercury from gas pumps in tritium facilities,

- Cadmium,

- Scintillation fluid, and

- Shipments from off-site (e.g., radioactive waste from military hardware).

Earthen trenches within the ORWBG were excavated 20 feet wide, 20 feet deep, and up to 700 feet long. The trenches were filled with the materials listed above. Trenches were covered with 4 feet or more of soil to reduce surface radiation to less than 6 $\mathrm{mR} / \mathrm{hr}$. Beginning in 1962 , records were kept of the contents, radiation level, and approximate storage location of each shipment of waste. Many of the waste volumes and radionuclide quantities were estimated, including information on waste disposed of before 1962. The location of the burial/storage area for each shipment of waste was defined by a 100 foot grid system laid out in 1962. These grids were further divided into 20 foot squares.

Until 1965, TRU waste contained within plastic bags and cardboard was buried in unlined trenches designated specifically for this waste. Between 1965 and 1972, TRU waste was segregated according to TRU content. Waste that did not fit into the prefabricated concrete containers was encapsulated in-place in concrete.

Inorganic constituents, such as lead (used to shield a variety of waste forms or discarded due to high contamination levels) and cadmium (from control rods, safety rods, and shielding), were placed in the ORWBG.

One trench in the east-central part of the ORWBG approximately 100 feet long was used for disposal of an unknown quantity of empty oil drums.

From 1953 through 1968, organic solvents were incinerated in open shallow unlined trenches located in the north-central part of the ORWBG. 


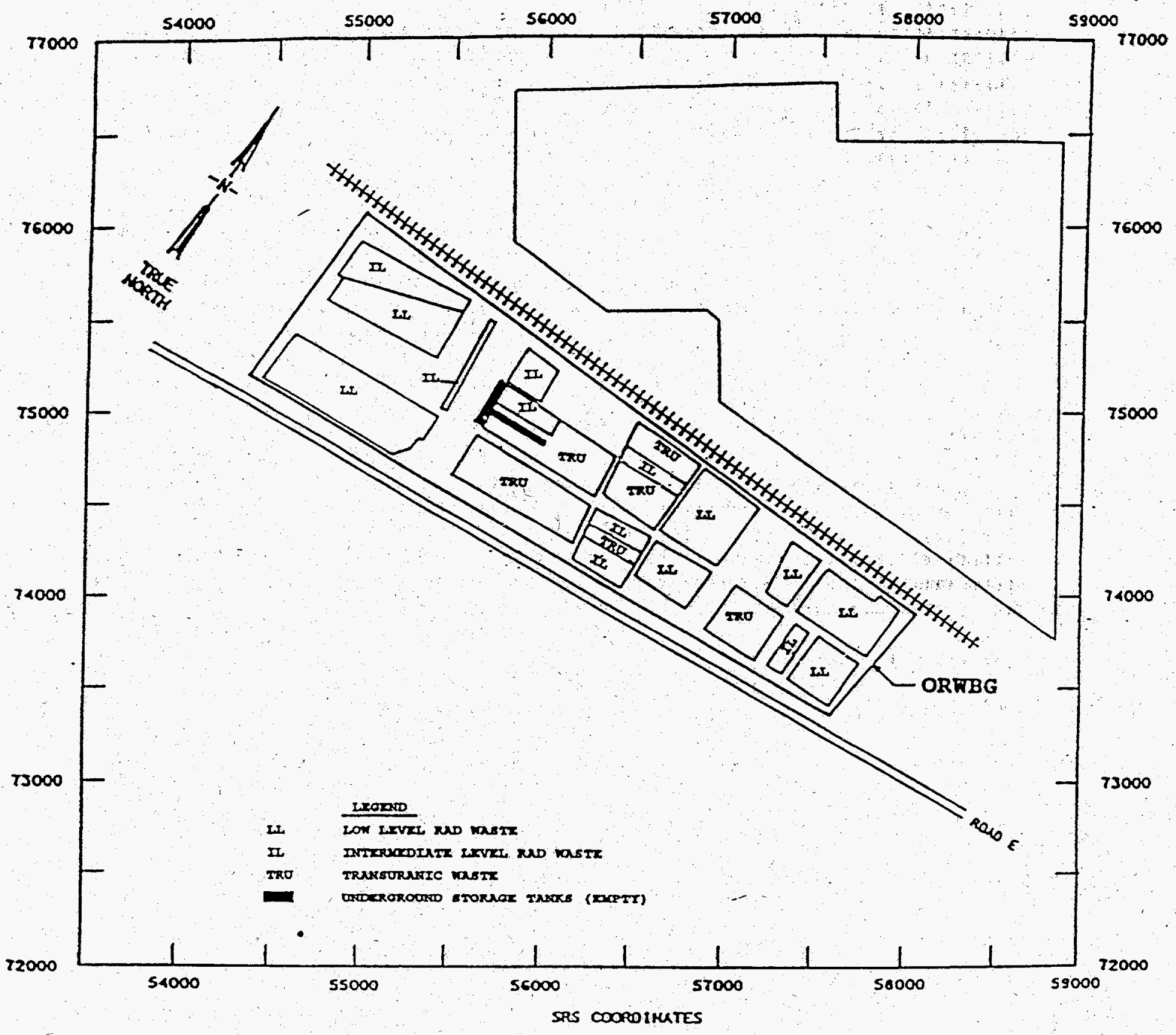

Figure 4. General Locations of Disposal Sections in the Old Radioactive Waste Burial Groúnd. 
Various solvents including napthalene, nparaffin, toluene, tributylphosphate (TBP), TBP-kerosene, trimethylbenzene, ultrasene, and xylene were stored in 22 underground storage tanks at the ORWBG. However, the cleanup of these tanks are not being addressed as part of this proposed interim action. The interim action for closure of the solvent tanks will be addressed in a separate proposed plan. The solvent tank interim action will not be completed in time to receive a soil cover and will therefore be without a cover until the final remedial action is initiated.

\section{Unit Area or Media to be Addressed}

This interim remedial action proposes placement of a soil cover over all of the ORWBG, except the solvent tanks and the existing operations/administration area. The solvent tanks were excluded because they require stabilization. In addition, the characterization for tank remediation is still in progress. The soil cover will control the leaching of hazardous substances from the source material, promote surface runoff, and minimize surface erosion.

\section{Section IV.B Operable Unit Risks}

\section{General Risk Information}

The estimated stormwater infiltration for the ORWBG existing conditions is $45 \%$ for a given rainfall event over a twenty year period. This value translates to a daily peak volume of 2.1 inches of water percolating from the bottom layer of the trenches. After installation of the soil cover, it is estimated that the stormwater infiltration will decrease to $13 \%$ for a given rainfall event over a twenty year period. This translates to a daily peak volume of 0.05 inches of water percolating from the bottom layer of the trenches. Therefore, the soil cover yields a $98 \%$ reduction in the amount of stormwater infiltrating into the ORWBG. Due to varying soil thickness and soil matrix variability over the entire area, a conservative estimate of at least a $70 \%$ reduction in the leachate production potential through the existing waste layer is anticipated (Serrato, 1994).

The reduction in stormwater infiltration is consistent with the goals of the National Oil and Substances Pollution Contingency Plan (NCP) because it provides risk reduction early in the investigation/assessment process without precluding any final action. The soil cover will control the source hazards by reducing contaminant migration and minimizing future groundwater remediation efforts. Additionally, the soil cover will not prevent initiation of any final action developed after full characterization and risk analysis have been completed for the BGC.

\section{Constituents of Concern (COCs)}

The focus of this interim action is to control the leaching of hazardous substances from the source material into the groundwater.

The information listed below was summarized from the RFIRI Work Plan for the Burial Ground Complex (U) (WSRC, 1994).

Soil gas surveys conducted at the ORWBG indicate that the chlorinated solvents tetrachloroethylene (PCE) and trichloroethylene (TCE) were observed to be widely distributed in the ORWBG. Observations of 1,1,1-trichloroethane were also observed, but were not as widely distributed as the PCE and TCE.

Scattered, low levels of carbon tetrachloride, chloroform, and trans-1,2-dichloroethylene were also observed. The most significant observations of trans-1,2-dichloroethylene were found in the central part of the ORWBG. Concentrations range from 201 to $1000 \mathrm{ppbv}$ and appear to correlate with low concentrations of PCE in this area. It is suggested that the trans-1,2dichloroethylene may be present as the result of biological degradation of PCE. 
Only a few, widely spaced observations of the aromatic hydrocarbons benzene, toluene, ethylbenzene, and xylenes were made in the ORWBG. The saturated hydrocarbons, $\mathrm{C}_{6}-$ C9, were observed with a slightly greater frequency than the aromatics. In particular, hexane, heptane, and octane are well correlated with the observations of trans1,2-dichloroethylene. No observations of decane were made. Pentane is widely distributed in low concentrations.

The levels of methane observed at the ORWBG vary. The larger levels of methane result from the anaerobic biological degradation of buried waste. Lower levels of methane and the other light hydrocarbons may be due to the natural background in this area.

Historically, groundwater data indicate that the tritium concentrations in wells monitoring the ORWBG average 140,745 $\mathrm{pCi} / \mathrm{mL}$ and range from $15 \mathrm{pCi} / \mathrm{mL}$ to nearly 30 million $\mathrm{pCi} / \mathrm{mL}$. The nonvolatile beta concentrations average $107 \mathrm{pCi} / \mathrm{L}$ and range from $0.15 \mathrm{pCi} / \mathrm{L}$ to greater than $9000 \mathrm{pCi} / \mathrm{L}$. The gross alpha concentrations average 4 $\mathrm{pCi} / \mathrm{L}$ and are generally less than $35 \mathrm{pCi} / \mathrm{L}$. As discussed earlier, radioactive materials were disposed of in sections of the ORWBG according to the type and level of radioactivity of the waste. Water samples containing high levels of tritium, nonvolatile beta emitters, or gross alpha emitters were obtained from wells monitoring sections of the ORWBG in which waste containing high concentrations of these constituents was buried. Concentrations of these constituents throughout the ORWBG thus vary considerably, and are generally much lower than the upper ranges noted above.

Metallic constituents have also been found in the ORWBG groundwater samples. These metals include cadmium, mercury, and lead. Mercury and lead concentrations have been shown to be highest in the northeast section of the ORWBG. Cadmium concentrations appear to be highest in the southwestern portion of the ORWBG.

Gas chromatography/mass spectrometry analysis of groundwater below the ORWBG indicated the presence of 63 organic compounds. Many of these compounds were indicative of spent solvent, oil and liquid scintillation wastes, and degradation products of humic substances. Four priority pollutants (benzene, toluene, phenol, and napthalene) were present in low concentrations. Acetophenone, a RCRA Appendix IX constituent, was tentatively identified in the groundwater.

The concentrations of ten priority pollutant volatile organic compounds detected in groundwater samples near the ORWBG include carbon tetrachloride, chloroform, 1,1-dichloroethane, 1,2-dichloroethane, 1,1dichloroethylene, trans-1,2-dichloroethane, toluene, PCE, TCE, and 1,1,1trichloroethane. Five of these volatile organic compounds (carbon tetrachloride, 1,2-dichloroethane, PCE, 1,1,1trichloroethane, and trans-1,2dichloroethane) occurred in concentrations above their respective maximum concentration limits. The highest number and concentrations of volatile organic compounds occurred along the southern boundary of the ORWBG.

Section IV.C Summary of the Considered Alternatives

Three alternatives were evaluated for interim action remediation of the contamination at the ORWBG. Each altemative is described below:

Alternative 1

No Action.

Alternative 2

Placement of a Soil Cover

Alternative 3

Placement of a RCRA-Like Cap 
All three altematives include engineering and administrative controls to guard against inadvertent human and ecological exposure to contamination Also, ongoing monitoring and approved characterization plans will continue during remediation.

The alternatives must meet or attain applicable or relevant and appropriate requirements (ARARs). The following statutes and regulations were reviewed as potential ARARs and To-Be-Considered (TBC) guidance:

- Atomic Energy Act

- RCRA

- Clean Air Act

- Safe Drinking Water Act

- Clean Water Act

- Toxic Substances Control Act

- South Carolina Pollution Control Act

- South Carolina Wastewater Regulations

- South Carolina Drinking Water Regulations

- South Carolina Air Pollution Control Regulations

- South Carolina Water Classification Standards

- South Carolina Well Standards and Regulations

- South Carolina Hazardous Waste Management Regulations

- Stormwater Management and Sediment Reduction

- DOE Orders

After reviewing the above mentioned statues and regulations, there were no locationspecific ARARs and TBC guidance identified. Chemical-specific and action-specific ARARs and TBC guidance are listed in Table 1 .

\section{Alternative 1 - No Action.}

Under Alternative 1, the ORWBG would remain in its current condition. Concentrations and activity levels of the COCs would gradually be reduced with time through natural attenuation processes such as dispersion and radioactive decay. Contaminated groundwater would continue to discharge into surface waters. Stormwater would continue to infiltrate into the trenches and leach contaminants into the groundwater. The no action alternative limits future characterization due to "As Low As Reasonably Achievable (ALARA)" issues.

Existing institutional controls, environmental monitoring, and site maintenance would continue and would be components of the no action alternative. This alternative is currently being implemented. There are no capital costs associated with this alternative. Maintenance and operation costs will not vary from alternative to alternative.

\section{Alternative 2 - Placement of a Soil Cover}

Under Alternative 2 , no buried waste material would be removed. $A$ lowpermeability soil cover would be installed on top of the existing grade. Topsoil (vegetative cover) would be added and the area compacted and seeded to prevent erosion.

The low-permeability soil cover will have a minimum thickness of 2 feet of compacted, low-hydraulic conductivity soil (in-place saturated hydraulic conductivity of $1 \times 10^{-5}$ $\mathrm{cm} / \mathrm{sec}$ or less) (Schiefer, 1995). The cover will also have an upper surface with a slope to prevent surface runoff and minimize surface erosion.

The topsoil (vegetative soil layer) will be placed at a minimum thickness of 3 inches and will have the ability to survive and function with little or no maintenance (Schiefer, 1995). The surface slope will also promote runoff and minimize surface erosion. 
Table 1. Applicable or Relevant and Appropriate Requirements and To-Be-Considered Guidance.

\begin{tabular}{|c|c|c|c|c|}
\hline Actions & Requirements & Prerequisites & Federal Citation & $\begin{array}{l}\text { South Carolina } \\
\text { Code of Laws }\end{array}$ \\
\hline \multicolumn{5}{|c|}{ CHEMICAL-SPECIFIC } \\
\hline $\begin{array}{l}\text { Protection of } \\
\text { the general } \\
\text { public from all } \\
\text { sources of } \\
\text { radiation }\end{array}$ & $\begin{array}{l}\text { The general public } \\
\text { must not receive an } \\
\text { effective dose } \\
\text { equivalent greater } \\
\text { than } 100 \text { mrem/year. } \\
\text { All releases of } \\
\text { radioactive material } \\
\text { must be ALARA }\end{array}$ & $\begin{array}{l}\text { Dose received by the } \\
\text { general public from all } \\
\text { sources of radiation } \\
\text { exposure at a DOE } \\
\text { facility - TBC } \\
\text { guidance } \\
\text { Releases of } \\
\text { radioactive material } \\
\text { from DOE activities - } \\
\text { TBC guidance } \\
\end{array}$ & $\begin{array}{l}\text { DOE Order } 5400.5 ; \\
\text { DOE Order } 5820.2 \mathrm{~A} \\
\text { DOE Order } 5400.5\end{array}$ & $\cdots$ \\
\hline \begin{tabular}{|l} 
Worker \\
Protection
\end{tabular} & $\begin{array}{l}\text { Maintain worker } \\
\text { exposures to ALARA } \\
\text { Radiation Protection } \\
\text { for Occupational } \\
\text { Workers }\end{array}$ & $\begin{array}{l}\text { Internal and external } \\
\text { sources of continuous } \\
\text { exposure to occupa- } \\
\text { tional workers at a } \\
\text { DOE facility - TBC } \\
\text { guidance } \\
\text { Control of radiation } \\
\text { exposures to occupa- } \\
\text { tional workers at a } \\
\text { DOE facility -ARAR }\end{array}$ & $\begin{array}{l}\text { DOE Order } 5480.11 \text {; } \\
\text { DOE Order } 5820.2 \mathrm{~A} \\
\text { 10CFR } 835\end{array}$ & \\
\hline \multicolumn{5}{|c|}{ ACTION-SPECIFIC } \\
\hline $\begin{array}{l}\text { Erosion } \\
\text { Control }\end{array}$ & $\begin{array}{l}\text { Develop a plan for } \\
\text { erosion sediment } \\
\text { control }\end{array}$ & $\begin{array}{l}\text { Land disturbing } \\
\text { activities - Applicable }\end{array}$ & & SC 72-300 \\
\hline $\begin{array}{l}\text { Closure } \\
\text { Activities }\end{array}$ & $\begin{array}{l}\text { During closure, resid- } \\
\text { ual radioactivity levels } \\
\text { for surface soils shall } \\
\text { comply with existing } \\
\text { DOE decommis- } \\
\text { sioning guidelines. } \\
\end{array}$ & $\begin{array}{l}\text { Disposal site closure } \\
\text { activities - TBC } \\
\text { guidance }\end{array}$ & DOE Order $5820.2 \mathrm{~A}$ & \\
\hline
\end{tabular}

Acronyms Used in Table 1.
ALARA
As Low As Reasonably Achievable
CFR Code of Federal Regulations
DOE
$S C$
Department of Energy
TBC
South Carolina
To-Be-Considered 
This cover could be easily repaired should destruction of portions of the cover occur through subsidence or cover intrusion be required for future assessments or remedial actions. The soil cover provides shielding for future waste/"hot spot" removal, if required (Frye-O'Bryant et al:; 1993). "Hot

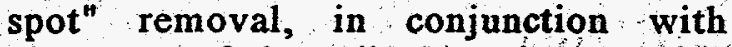
placement of the soil cover, is not being proposed at this time, based on the following:

- the nonhomogeneous nature and disposition of the wastes in the ORWBG (landfill-like)

- "hot spot" source exact location is unknown (within the waste unit)

- current characterization technologies would not provide location of "hot spot" sources, and

- if the BGC RFI/RI/FS process concludes "hot spot" source and/or "waste retrievals" are to be done, this interim action soil cover will not preclude that action and will provide additional shielding for the final action remediation workers.

The existing groundwater monitoring wells within the covered area will need to be extended to meet the increased elevation or abandoned (Frye-O'Bryant et al., 1993).

Existing institutional controls, environmental monitoring, and site maintenance would also be components of this alternative. Visual inspection of the soil cover will be performed by trained individuals at regular intervals and after significant rainstorms. Any observed damage, erosion, or subsidence will be repaired to conform with the original soil cover contours.

This alternative could be implemented in approximately 18 months. This timeframe is required for the construction activities related to erosion control, the sedimentation basin, and the soil and vegetative covers. The time required for preparation and regulatory approval of the IAPP, Interim
Action Record of Decision (IROD), and the combined Remedial Design/Remedial Action Work Plan/Remedial Design Report is independent of the 18 months required for construction.

The estimated capital cost for this alternative is $\$ 10$ million for 76 acres. The cost estimate is based on previous closure cover systems constructed at the SRS and economic evaluation studies for closure cover systems at hazardous waste units. The estimated unit cost for this alternative is $\$ 3$ per square foot. The major subtasks associated with this alternative are:

- design and construction of the soil layer,

- stormwater management system design, construction, and permitting,

- health and safety documentation development, and

- support and indirect tasks.

Maintenance and operation costs will not vary from alternative to alternative.

\section{Alternative 3 - Placement of a RCRA- Like Cap}

Under Alternative 3, no buried waste would be removed. The existing cover soil will be prepared for the placement of the foundation layer. Once the foundation layer is placed, placement of the final lowpermeability cover system (cap) will be completed. The cap could possibly consist of the following materials: geogrid, geosynthetic clay liner, flexible membrane liner, and a geocomposite drainage layer. Topsoil (vegetative cover) would be added and the area compacted and seeded to prevent erosion.

The cap would meet more stringent criteria (e.g., $1 \times 10^{-7} \mathrm{~cm} / \mathrm{s}$ permeability or less) and the topsoil (vegetative cover) would meet the same requirements as described in Alternative 2. The cap complicates implementation of future characterization, if required; without loss of containment 
integrity. The groundwater monitoring wells will also need to meet the same requirements as listed in Altemative 2.

Existing institutional controls, environmental monitoring, and site maintenance would also be components of this alternative.

this alternative

This alternative could be implemented in approximately 24 months. This timeframe is required for the construction activities related to the RCRA-like cap. The time required for preparation and regulatory approval of the IAPP, IROD, and the combined Remedial Design/Remedial Action Work Plan/Remedial Design Report is independent of the 24 months required for construction.

The estimated capital cost for this alternative is $\$ 25$ million for 76 acres. The cost estimate is based on previous closure cover systems constructed at the SRS and economic evaluation studies for closure cover systems at hazardous waste units. The estimated unit cost for this alternative is \$7.5 per square foot. The major subtasks associated with this alternative are:

- design and construction of the RCRA-like cap,

- stormwater management system design, construction, and permitting

- health and safety documentation development, and

- support and indirect tasks.

Maintenance and operation costs will not vary from altemative to altemative.

Section IV.D Evaluation of the Alternatives and the Preferred Alternative

\section{Description of Nine Evaluation Criteria}

Each of the interim remedial alternatives was evaluated using the nine criteria established by the NCP. The criteria were derived from the statutory requirements of
CERCLA Section 121. The NCP [40 CFR \& 300.430 (e) (9)] sets forth nine evaluation criteria that provide the basis for evaluating alternatives and selecting a remedy. The critería are:

- overall protection of human health and the environment,

- compliance with ARARs,

- long-term effectiveness and permanence,

- reduction of toxicity, mobility, or volume through treatment,

- short-term effectiveness,

- implementability,

- cost,

- state acceptance, and

- community acceptance.

Brief descriptions of these criteria are given below.

Overall Protection of Human Health and the Environment - The interim action remedial alternatives are assessed to determine whether they adequately protect human health and the environment from unacceptable risks posed by hazardous substances at the unit. The alternatives must eliminate, reduce, or control exposure levels established during development of remediation goals.

Compliance with Applicable or Relevant and Appropriate Requirements (ARARs) ARARs are Federal and state environmental regulations that establish standards which remedial actions must meet. There are three types of ARARs: (1) chemical-specific, (2) location-specific, and (3) action-specific.

Chemical-specific ARARs are usually healthor risk-based levels or methodologies which, when applied to unit-specific conditions, result in the establishment of numerical values. These values establish the acceptable amount or concentration of a chemical that may be found in, or discharged to, the surrounding environment. Often these numerical values are promulgated in Federal or state regulations. 
Location-specific ARARs are restrictions placed on the concentration of hazardous substances or the conduct of activities solely because they are in specific locations. A unit's location is a fundamental determinant of its impact on human health and the environment. Some examples of specific locations include floodplains, wetlands, historic places, and sensitive ecosystems or habitats.

Action-specific ARARs are usually technology- or remedial activity-based requirements or limitations on actions taken with respect to hazardous substances or unitspecific conditions. These requirements are triggered by the particular remedial activities that are selected to accomplish a remedy.

The remedial activities are assessed to determine whether they attain ARARs or provide grounds for invoking one of the five waivers for ARARs. These waivers are:

- the remedial action is an interim measure and will become a part of a total remedial action that will attain the ARAR,

- compliance will result in greater risk to human health and the environment than other alternatives,

- compliance is technically impracticable from an engineering perspective,

- the alternative remedial action will attain an equivalent standard of performance through use of another method or approach,

- the state has not consistently applied the promulgated requirement in similar circumstances or at other remedial action in the state.

Long-Term Effectiveness and Permanence The interim action remedial alternatives are assessed for long-term effectiveness and permanence as well as the degree of certainty that the alternative will prove successful. Factors considered include the magnitude of the residual risk from untreated waste following implementation of the alternative. Another concern is the adequacy and reliability of controls (e.g., containment systems and institutional controls) to manage treatment of residuals and untreated waste.

Reduction of Toxicity Mobility or Volume Through Treatment - The interim action remedial alternatives are assessed based on the degree to which they employ treatment that reduces toxicity, mobility, or volume of contaminants associated with the unit.

Short-Term Effectiveness - The interim action remedial alternatives are assessed considering factors relevant to implementation of the remedial action, including risks to the community during implementation, impacts on workers, potential environmental impacts (e.g., air emissions), and the time until protection is achieved.

Implementability - The interim action remedial alternatives are assessed by considering the difficulty of implementing the alternative including technical feasibility, constructability, reliability of technology, ease of undertaking additional remedial actions (if required), monitoring considerations, administrative feasibility (regulatory requirements), and availability of services and materials.

Cost - The evaluation of remedial alternatives must include capital and operational and maintenance costs. Present worth costs are estimated within $+50 /-30$ percent, per EPA guidance. In estimating the present worth cost, a discount rate of five percent is used and inflation is considered to be zero percent. This discount represents the estimate of dollar value in future years: A sensitivity analysis will be used when sufficient uncertainty exists regarding the design, implementation, operation, or effective life of an alternative. The cost estimates given with each alternative are prepared from information 
available at the time of the estimate. The final costs of the project will depend on actual labor and material costs, actual site conditions, productivity, competitive market conditions, final project scope, final project schedule, and other variable factors. As a result, the final project costs may vary from the estimates presented herein.

State Acceptance - The alternatives assessment must evaluate state concerns. State acceptance will be addressed through the state's participation in the FFA process.

Cemmunity Acceptance - Community comments regarding the various components of altematives will be assessed. Public comments concerning the proposed remedy will be incorporated into the Responsiveness Summary of the IROD.

The interim remedial action alternatives discussed in the Section IV.C have been evaluated using the nine criteria just described. Table 2 presents the evaluation of the alternatives.

\section{Description of the Preferred Alternative}

Alternative 2, Placement of a Soil Cover, has been selected as the preferred interim action. This alternative consists of placement of a low-permeability soil cover (minimum thickness 2 feet) on top of the existing grade." Topsoil (vegetative soil layer - minimum thickness of 3 inches) would be added and the area compacted and seeded to prevent erosion. The estimated capital costs for this alternative is $\$ 10$ million for 76 acres. A combined Remedial Design/Remedial Action Work Plan/Remedial Design Report will be submitted for regulatory review in March 1996. This combined document will provide additional details regarding the soil cover.

Visual inspection of the soil cover will be performed by trained individuals at regular intervals and after significant rainstorms. Any observed damage, erosion, or subsidence will be repaired to conform with the original soil cover contours.

This alternative was selected because it would (1) decrease the stormwater infiltration rate and contaminant migration to the groundwater, thus minimizing future impacts to the groundwater, (2) provide increased radiation shielding from buried waste at the ground surface, (3) be easily repaired should destruction of portions of the cover occur through subsidence, and (4) provide versatility for future characterization and removal activities. A cross-section of this alternative is shown in Figure 5. The cross-section is representative of one of the eight proposed soil cover sections.

Alternative 2 is an interim action and in no way constitutes a final action for the ORWBG. A final remedial action will be evaluated and conducted in the future according to requirements of the FFA. The solvent tanks remediation will be addressed at that time. 
Table 2. Evaluation of Alternative Actions Considered for Remediation of ORWBG Contamination.

\begin{tabular}{|c|c|c|c|}
\hline Evaluation Criteria & $\begin{array}{l}\text { Alternative } 1 \\
\text { No Action }\end{array}$ & $\begin{array}{l}\text { Alternative } 2 \\
\text { Placement of a Soil Cover, } \\
\text { Without Excavation and } \\
\text { Removal of Buried Waste }\end{array}$ & $\begin{array}{c}\text { Alternative } 3 \\
\text { Placement of a RCRA-Like } \\
\text { Cap, Without Excavation } \\
\text { and Removal of Buried } \\
\text { Waste }\end{array}$ \\
\hline $\begin{array}{l}\text { Overall Protection of Human } \\
\text { Health and the Environment }\end{array}$ & Minimal & $\begin{array}{l}\text { This alternative is protective of } \\
\text { human health and the } \\
\text { environment. }\end{array}$ & $\begin{array}{l}\text { This alternative is protective of } \\
\text { human health and the } \\
\text { environment. }\end{array}$ \\
\hline Compliance with ARARs & $\begin{array}{l}\text { There are no ARARs associated } \\
\text { with this alternative. }\end{array}$ & $\begin{array}{l}\text { Other than worker protection } \\
\text { standards, there are no ARARs } \\
\text { associated with this alternative. }\end{array}$ & $\begin{array}{l}\text { Other than worker protection } \\
\text { standards, there are no ARARs } \\
\text { associated with this alternative. } \\
\text { However, RCRA guidance on caps } \\
\text { are To-Be-Considered. }\end{array}$ \\
\hline $\begin{array}{l}\text { Long-term effectiveness and } \\
\text { permanence }\end{array}$ & $\begin{array}{l}\text { This evaluation criteria does not } \\
\text { apply to Interim Actions. }\end{array}$ & $\begin{array}{l}\text { This evaluation criteria does not } \\
\text { apply to Interim Actions. }\end{array}$ & $\begin{array}{l}\text { This evaluation criteria does not } \\
\text { apply to Interim Actions. }\end{array}$ \\
\hline $\begin{array}{l}\text { Reduction of toxicity, mobility, } \\
\text { or volume through treatment }\end{array}$ & $\begin{array}{l}\text { This altemative does not reduce } \\
\text { toxicity, mobility, or volume } \\
\text { through treatment since there is } \\
\text { no treatment process. }\end{array}$ & $\begin{array}{l}\text { This interim remedial action will } \\
\text { decrease leachate production } \\
\text { and will reduce contaminant } \\
\text { transport to the groundwater and } \\
\text { as such a reduction in mobility } \\
\text { of contaminants will occur. }\end{array}$ & $\begin{array}{l}\text { This interim remedial action will } \\
\text { decrease leachate production and } \\
\text { will reduce contaminant transport } \\
\text { to the groundwater and as such a } \\
\text { reduction in mobility of } \\
\text { contaminants will occur. This } \\
\text { alternative provides a greater } \\
\text { reduction in mobility of } \\
\text { contaminants than Altemative } 2\end{array}$ \\
\hline Short-term effectiveness & $\begin{array}{l}\text { This alternative does not provide } \\
\text { a short-term remedy for } \\
\text { preventing discharges of } \\
\text { contaminated groundwater to } \\
\text { surface streams. }\end{array}$ & $\begin{array}{l}\text { This alternative will decrease } \\
\text { leachate production and will } \\
\text { reduce contaminant transport to } \\
\text { the groundwater. }\end{array}$ & $\begin{array}{l}\text { This altemative will decrease } \\
\text { leachate production and will } \\
\text { reduce contaminant transport to } \\
\text { the groundwater. }\end{array}$ \\
\hline
\end{tabular}


Table 2. Evaluation of Alternative Actions Considered for Remediation of ORWBG Contamination (cont'd).

\begin{tabular}{|c|c|c|c|}
\hline Evaluation Criteria & $\begin{array}{c}\text { Alternative } 1 \\
\text { No Action }\end{array}$ & $\begin{array}{l}\text { Alternative } 2 \\
\text { Placement of a Soil Cover, } \\
\text { Without Excavation and } \\
\text { Removal of Buried Waste }\end{array}$ & $\begin{array}{c}\text { Alternative } 3 \\
\text { Placement of a RCRA-Like } \\
\text { Cap, Without Excavation } \\
\text { and Removal of Buried } \\
\text { Waste }\end{array}$ \\
\hline $\begin{array}{l}\text { Short-term effectiveness } \\
\text { (cont'd) }\end{array}$ & & $\begin{array}{l}\text { Since risks to the offsite } \\
\text { population are minimal, no } \\
\text { measures to protect the } \\
\text { community will be required } \\
\text { during remediation and during } \\
\text { the time period before remedial } \\
\text { goals are met. Protection of } \\
\text { workers will be required during } \\
\text { cover installation. Monitoring } \\
\text { of this area will continue and } \\
\text { therefore, exposure to the } \\
\text { current (non-remediation) } \\
\text { workers will be reduced. }\end{array}$ & $\begin{array}{l}\text { Since risks to the offsite } \\
\text { population are minimal, no } \\
\text { measures to protect the } \\
\text { community will be required during } \\
\text { remediation and during the time } \\
\text { period before remedial goals are } \\
\text { met. Protection of workers will be } \\
\text { required durng cover installation. } \\
\text { Monitoring of this area will } \\
\text { continue and therefore, exposure } \\
\text { to the current (non-remediation) } \\
\text { workers will be reduced. }\end{array}$ \\
\hline Implementability & $\begin{array}{l}\text { This alternative is already in } \\
\text { place. }\end{array}$ & $\begin{array}{l}\text { The cover material is readily } \\
\text { available from onsite sources. } \\
\text { This alternative could be } \\
\text { implemented in about } 18 \\
\text { months. This timeframe does } \\
\text { not include the time necessary } \\
\text { for document preparations, } \\
\text { regulatory review, etc. }\end{array}$ & $\begin{array}{l}\text { The cap materials are available } \\
\text { from off-site vendors. This } \\
\text { alternative could be implemented } \\
\text { in about } 24 \text { months. This } \\
\text { timeframe does not include the } \\
\text { time necessary for document } \\
\text { preparations, regulatory review, } \\
\text { etc. }\end{array}$ \\
\hline Cost & Capital Cost $=$ None & Capital Cost $=$ app. $\$ 10$ million & Capital Cost $=$ app. $\$ 25$ million \\
\hline State Acceptance & $\begin{array}{l}\text { This criterion will be completed } \\
\text { following review by the } \\
\text { appropriate regulatory agencies. }\end{array}$ & $\begin{array}{l}\text { This criterion will be completed } \\
\text { following review by the } \\
\text { appropriate regulatory agencies. }\end{array}$ & $\begin{array}{l}\text { This criterion will be completed } \\
\text { following review by the } \\
\text { appropriate regulatory agencies. }\end{array}$ \\
\hline Community Acceptance & $\begin{array}{l}\text { This criterion will be completed } \\
\text { following public review. }\end{array}$ & $\begin{array}{l}\text { This criterion will be completed } \\
\text { following public review. }\end{array}$ & $\begin{array}{l}\text { This criterion will be completed } \\
\text { following public review. }\end{array}$ \\
\hline
\end{tabular}




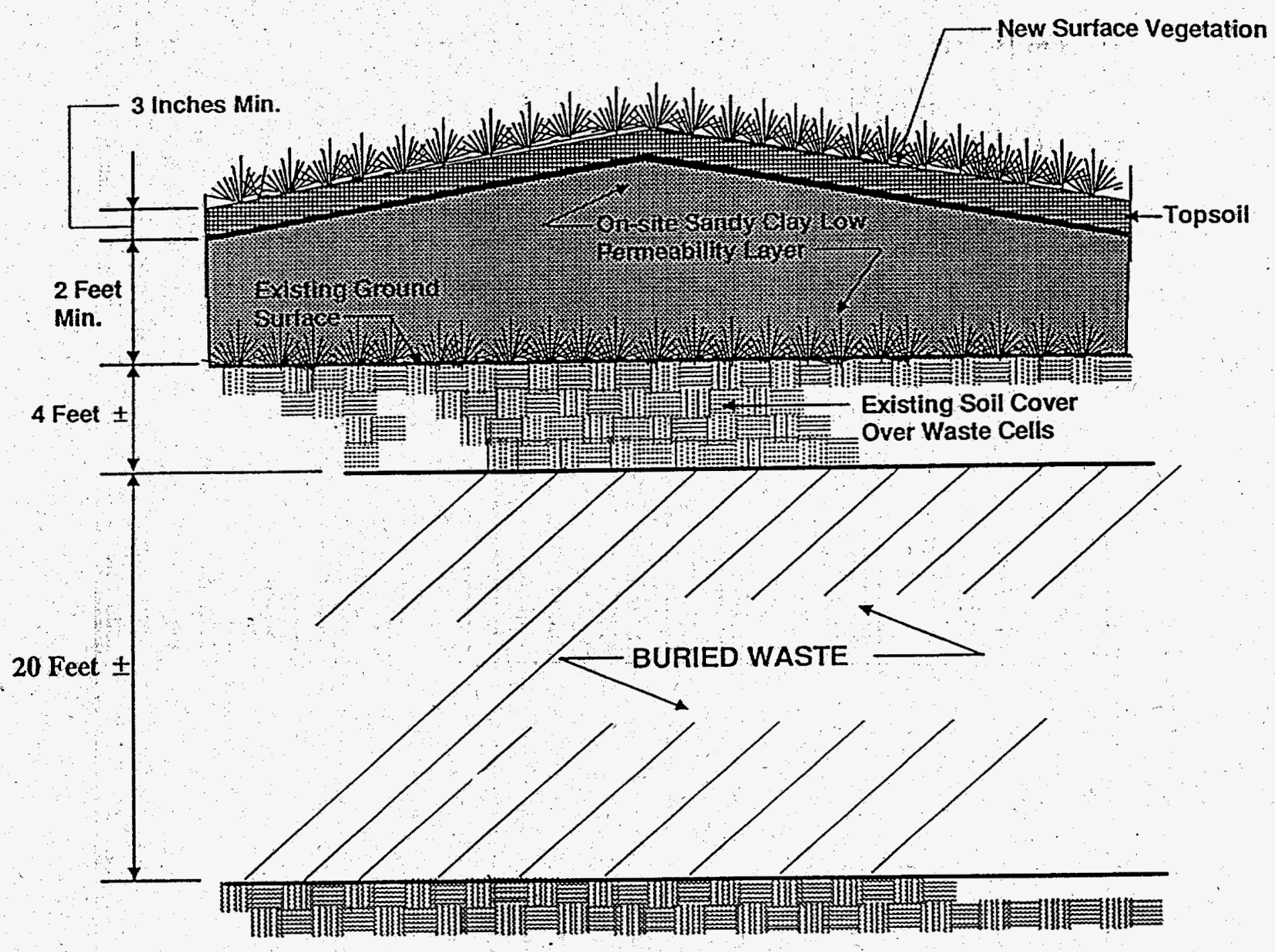

This cross-section is representative of one of the eight proposed soil cover sections.

Figure 5. Old Radioactive Waste Burial Ground Soil Cover Configuration. 
पpnos "uəy!V sureduros eullores

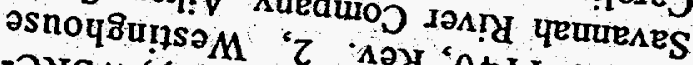
- OASM (N) xajdrio puno I I -0.6-dy

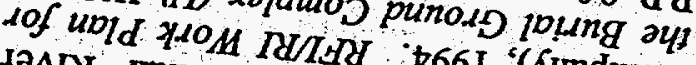
Jonty qeutenes osnopol (Kurduos

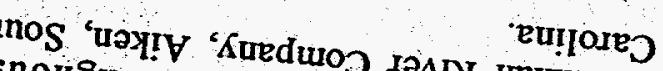
asnoysu!nsoM '8ZT ron!Y Yeutrenes

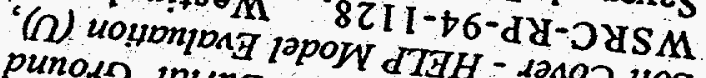
punoss loung plo 661 I $\therefore$ opres

"Kurduros lonty quutores hnos 'urytV

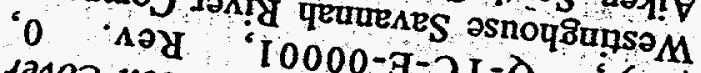
LanoD lios uाнगय a1soM axyobotppy plo punos lolkng słuawaגinbay ysol PIO :olsath pub a '

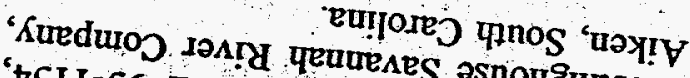

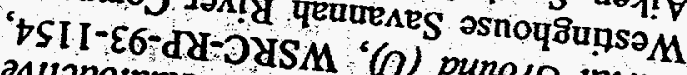

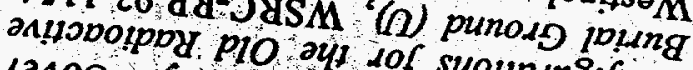
1010D kioiodiua lof suoundnsyuos E66I olenss fo uolloniong \& $S$ treyanen

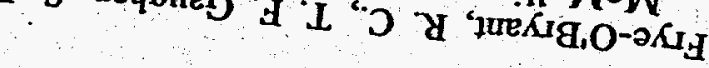

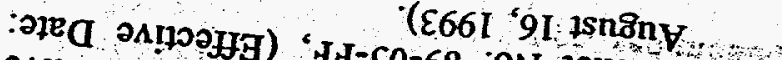

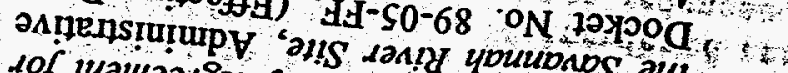

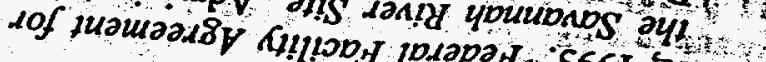

VAS

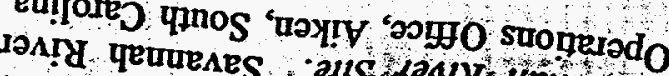

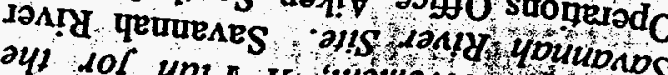

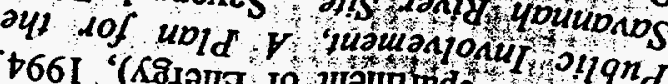

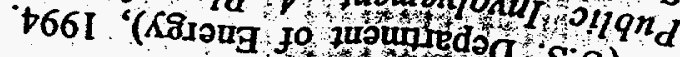




\section{GLOSSARY}

Administrative Record File: $A$ file that is maintained and contains all information used to make a decision on the selection of a response action under the Comprehensive Environmental Response, Compensation, and Liability Act. This file is to be available for public review, and a copy is to be established at or near the Site, usually at one of the information repositories. Also, a duplicate file is held in a central location, such as a regional or state office.

ARARs: Applicable or Relevant and Appropriate Requirements, Refers to the federal and state requirements that a selected remedy will attain. These requirements may vary from site to site.

Capital Costs: Money spent for longterm additions or improvements and charged to a capital assets account.

Characterization: The compilation of all available data about the waste units to determine the rate and extent of contaminant migration resulting from the waste site, and the concentration of any contaminants that may be present.

Comprehensive Environmental Response, Compensation, and Liability Act (CERCLA): Comprehensive Environmental Response, Compensation, and Liability Act of 1980 which is commonly referred to as CERCLA was amended by the Superfund Amendments Reauthorization Act (SARA) of 1986.

Contamination: The deposition of unwanted chemical and/or radioactive material at a site.

Federal Facility Agreement (FFA): The legally binding agreement between regulatory agencies (EPA and SCDHEC) and regulated entities (DOE) that sets the standards and schedules for the comprehensive remediation of the SRS.
Interim Action: A event or series of events, including remedial actions, performed prior to or concurrent with the conduction of an RI/FS as information is made sufficient to support a remedy selection.

Media: A pathway through which contaminants are transferred. Five media by which contaminants may be transferred are groundwater, soil, surface water, sediments, and air.

National Priorities List (NPL): Formal listing of the nation's worst contaminated sites, as established by the Comprehensive Environmental Response, Compensation, and Liability Act.

Operable Unit: Defined in the regulations as a discrete action taken as one part of an overall site cleanup. The term is also used in EPA guidance documents to refer to distinct geographic areas or media-specific units within a site. $A$ number of operable units can be used in the course of a cleanup.

Operation and Maintenance (O\&M): Activities conducted at a site after a response action occurs to ensure that the cleanup and/or systems are functioning properly.

Overall Protection of Human Health and the Environment: The assessment against this criterion describes how the alternative, as a whole, achieves and maintains protection of human health and the environment.

Proposed Plan: A legal document that provides a brief analysis of remedial alternatives under consideration for the site/operable unit and proposes the preferred alternative.

Reduction of Toxicity, Mobility, and Volume through Treatment: The assessment against this criterion evaluates. the anticipated performance of the specific 
treatment technologies an alternative may employ.

Resource Conservation and Recovery Act (RCRA): Resource Conservation and Recovery Act of 1976 which is commonly referred to as RCRA, is an amendment to the first federal solid waste legislation, called the Solid Waste Disposal Act of 1965. RCRA was amended in 1980 and most recently on November 8,1984 by the Hazardous and Solid Waste Act.

Record of Decision (ROD): A legal document that describes the final remedial actions selected for a site, why the remedial actions were chosen, and how the public responded to the proposed remedial actions.

Responsiveness Summary: A summary of oral and/or written comments received during the proposed plan comment period.

Superfund: The common name used for the Comprehensive Environmental Response, Compensation, and Liability Act. The superfund program was established to help fund cleanup of hazardous waste sites. It also allows for legal action to force those responsible for the sites to clean them up. 